\title{
THE PROCESS OF EDUCATION IN THE FIELD AND TEACHER FORMATION IN BRAZIL
}

\author{
Maurício Fagundes $1{ }^{1}$ (iD), Silvana Cassia Hoeller 2 四 (iD) \\ 1 Programa de Pós-Graduação em Educação, Universidade Federal do Paraná, Brasil \\ 2 Curso de Agroecologia, Universidade Federal do Paraná, Brasil
}

DOI: https://doi.org/10.29121/granthaalayah.v9.i1.2021.2965

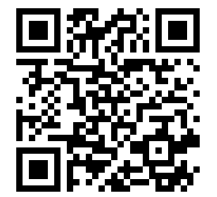

Article Type: Research Article

Article Citation: Maurício

Fagundes, and Silvana Cassia

Hoeller. (2021). THE PROCESS OF

EDUCATION IN THE FIELD AND

TEACHER FORMATION IN BRAZIL.

International Journal of Research -

GRANTHAALAYAH, 9(1), 16-24.

https://doi.org/10.29121/granthaa

layah.v9.i1.2021.2965

Received Date: 25 December 2020

Accepted Date: 22 January 2021

Keywords:

Camp Education

Teacher Formation

Social Movements

\begin{abstract}
This article aims to discuss the training of teachers for field education, referenced in the historical-political process that began at the end of the Brazilian military dictatorship. With the process of democratization experienced in Brazil since the mid-1980s, with the end of the military dictatorship, we highlight the transition from rural education to education in the field and the respective training of teachers to meet this specific demand. This process was made up of a public policy, the fruit of the mobilization of social movements. The need for teacher training gave rise to the graduation courses in Field Education, which work primarily with subjects who are inserted in the reality of the field, through the pedagogy of alternation and itinerancy. The methodology that contributes to this work is of a qualitative nature, developed through bilbiographical research, with a temporal cut from 1985 to 2018 . As a conclusion, it is possible to point out that the degrees in Education in the Field, currently, are a reality as an educational process, which meets the specificities of the subjects in the field, reinforcing their identities and contemplating the specificities in several Brazilian regions, thus moving towards overcoming the existing conservative education and named as rural.
\end{abstract}

\section{INTRODUCTION}

The national context, which preceded the process of the policies that implemented the bachelor's degrees in field education, can be dated as the end of the eighties, a period in which Brazil experienced the end of the period of military dictatorship and the beginning of the period that was conventionally called redemocratization. Civil society carried with it the desire to overcome the period without freedoms, demarcated by military governments since 1964.

In the midst of these movements and expectations of building a democratic society, there was a great national mobilization, awakening the formation of several social movements that began to raise their flags of struggle. One of them was promoted by the Landless Workers' Movement, which from the struggle for land expanded to the struggle for a formation that would break with the process of tutelage developed until then.

One of the results of these tensions was the creation of the Licentiate's Degree in Field Education, with the purpose of carrying out teacher training with the political-pedagogical intention of respecting the concrete reality of the man/woman of the field, that is, opposing the logic of the market or commonly called traditional pedagogy.

This article aims to discuss the formation of teachers from the historical-political process that originated them. The methodology behind this work is of a qualitative nature, developed through bilbiographical research, with a

(C) 2021 The Author(s). This is an open access article distributed under the terms of the Creative Commons Attribution License, which permits unrestricted use, distribution, and reproduction in any medium, provided the original author and source are credited. 
Maurício Fagundes, and Silvana Cassia Hoeller

temporal cutout of the period that ended the military regime in Brazil, 1985, a moment marked by the resumption of redemocratization, until the year 2018.

The text that follows begins with the historical and political context that demarcates the transition from rural education to field education, highlighting the multiple public movements and policies resulting from them. It follows the architecture of the curricular organization of the Federal University of Paraná - Coastal Sector, which gives rise to the foundation of the Degree in Field Education, which is now discussed as one more part of this article. The text ends with the alignment of some provisional conclusions and references.

\subsection{THE BRAZILIAN CONTEXT OF THE 1980 AND THE PROCESS OF TRANSITION FROM RURAL EDUCATION TO EDUCATION IN THE FIELD}

In the yearning for the exercise of civil and citizen liberties, the late 1980s and early 1990s were marked by a great mobilization of civil society, seeking to rethink and democratically reorganize institutions with a view to the process of discussion and construction of a new Constitution for Brazil. The resumption of civil rights led to the articulation of corporate groups, social movements, unions and politicians who, around their ideas, stimulated the discussion of projects for the Brazilian nation, putting them into question.

Education was strongly part of these debates, including, significantly, the reflection on the role reserved for universities as the central theme of the discussions. The democratization of power structures in the administration of Higher Education Institutions - IES - favored the explanation of projects that, sometimes, were confronted, however, allowing the exercise of a protagonism still unpublished for most of their communities (CUNHA; FAGUNDES, 2008). As Chico Buarque, Brazilian poet and singer, says in his song Roda Viva (1967) period of the Brazilian military dictatorship: "we want to have an active voice in our destiny to command", and thus, it was a moment of political awakening and rights.

From this historical movement of redemocratization we can highlight the Federal Constitution of 1988 and the Law of Directives and Bases of Education - LDB 9.394 of 1996 - as two legal milestones that recognized education as a right. LDB emphasizes the specificity of the rural in education, highlighting its distinct peculiarities from urban education. This is verified in articles 23, 26 and 28, which discuss the curriculum and the organization of school times.

LDB 9.394/96 (2017, p. 17) ended up signaling alternatives for the organization of basic schooling in line with the reality of life and work in rural communities, as expressed in art. 23: "basic education may be organized in annual series, semester periods, cycles, regular alternation of study periods, non-serial groups, based on age, competence and other criteria [...]". Regarding the different realities of men and women in the countryside, article 23 is complemented by $\S 2$, which says: "the school calendar should be adapted to local peculiarities, including climatic and economic, at the discretion of the respective teaching system, without reducing the number of teaching hours provided for in this Law.

In art. 26 of LDB 9.394/96 (2017, p. 19) there was an opening for some specificities that complemented the common national base: "a diversified part, demanded by the regional and local characteristics of society, culture, economy and students". And art. 28 made it explicit that each locality will be able to adapt the contents and methodologies to the reality lived by rural populations.

As is well known, the approval of laws and guidelines are not enough to change realities, because even today the school maintains the same status quo, as Leite (1999) problematizes, when it highlights aspects present in the Brazilian nation, such as the low income of rural populations, cultural devaluation, the presence of lay teachers, low teacher salaries, lack of specific training for teachers, lack of community participation in school decisions, the difficulty in changing the political and pedagogical school project, the rural exodus, the closing of schools, the nucleation of school units, the reproduction of the urban curriculum and the political and economic disinterest of public power in meeting the needs of rural schools. Despite regulatory frameworks, public policy itself did not materialize in the reality of the subjects, in the dimension desired by the movements that created it.

The difficulty of concretizing public policies in such a way as to modify the reality of the subjects for whom it is intended has made the contradictions reaffirm themselves, generating other contexts in which the movements of struggle for land have intensified occupations and demands for agrarian reform. At that moment the agenda of demands was expanded and the struggle for land joined the struggle for education, because the social movements 
The Process of Education in The Field and Teacher Formation in Brazil

understood that there was a need to have land, but also to have an education that would fulfill the complexities of these subjects in the countryside.

Without exhausting the different contexts and contradictions that represented the moment, social organizations emerged that in 1997 held "the first National Meeting of Agrarian Reform Educators (I ENERA), with support from UNICEF and UNB" (ARROYO; FERNANDES, 1999, p. 58).

At the end of the meeting, a manifesto was produced that brought some conceptions about public education in the relationship with rural populations. In this manifesto there were some important points to understand how rural education was born, since it announced a new perspective of thinking about the education that was being managed in the movements coming from the countryside. Thus, we highlight some points of the manifesto, in the intention of dialoguing with aspects that were fruit of the lived reality of these subjects and the expectations of transformation.

The manifesto made explicit the fundamental importance of education in the processes of social transformation, in spite of showing the clarity that it alone does not solve the problems of society. The need to guarantee the quality of public schooling from early childhood education to higher education was a demand that came and meets the intentions of the State; as evidenced by the INEP numbers, there is practically no high school in the rural area and this was one of the demands of social movements.

The manifesto also brought aspects of reaffirmation of the need for a specific education for the populations of the countryside with elements linked to the concreteness of life. The fundamental of the manifesto referred to the right to think and to participate in decisions on educational policy. This demand was an issue that generated a historical tension, in which programs and projects represented the bias of policies thought from above, detached from reality, far from concreteness and the possibility of overcoming.

A school that developed an educational process based on action and democratic participation, on the educational dimension of work, culture and history of the people of the countryside was called for. In other words, this translates the search for an identity of rural schools, that can have their own pedagogical political projects, built not only by the school, but with the community (FOLHA DE S. PAULO, 1997).

In the I ENERA, the movement of change in language was unleashed, resignifying the words used in education, such as: "rural education for education of and in the countryside", "we are educators and educators", in this expression the subjects place themselves as actors of the educational process, saying in a Freirean way (mention to educator Paulo Freire); the words became pregnant with meanings.

According to the National Institute of Colonization and Agrarian Reform - INCRA (2017), from the movement that represented the I ENERA derived a working group from universities to think and propose an education in the field, since there was the absence of a specific public policy in the National Education Plan for schools in the field. In addition, Brazil's First Census of Agrarian Reform, held in 1996 but published in a report in 1997, showed a high rate of illiteracy in settlement areas of the National Agrarian Reform Program, reaching about 43\%. Related to this problem, priority was given to developing a public policy that would respond to the emerging demand of youth and adult illiteracy.

In 1998, through Ordinance No. 10/98, the Extraordinary Ministry of Land Policy created the National Program for Education in Agrarian Reform (PRONERA). In 2001, the Program was incorporated into the National Institute of Colonization and Agrarian Reform (INCRA, 2004). According to the 1998 report by the Extraordinary Ministry of Land Policy - MEPF, "the PRONERA is an instrument to respond, with specific methodologies, to social demands for education of settlers. This report is entitled "A Escola do Campo". It is noticeable that there has been an initiative for change, since at first the term rural to field is changed.

This movement resulted in the organization of the First Conference for a Basic Education in the Field, promoted by the CNBB, MST, UNICEF, UNESCO and UNB partnership (ARROYO; CALDART; MOLINA, 2004) and had the intention of denouncing to the society, the historical debt to the populations of the countryside, as well as the lack of public policies for the sector and of "placing the basic education project in the countryside" (ARROYO; FERNANDES, 1999, p. 18).

In the 1st Conference for a Basic Education in the Field, the concepts that were used to give concreteness to the education in the field were constructed, as the authors Kolling, Nery and Molina (1999, p. 63) bring:

[...] a field school is one that works from the interests, politics, culture and economy of the various groups of field workers [...] Political identification and geographic insertion into the cultural reality of the countryside are fundamental conditions for its implementation. 
From this space emerge the bases for the construction of the Operational Guidelines for Basic Education in Field Schools (BRAZIL, 2001), which began to contemplate the specificities of an education in and from the field, as emphasized in Article 5 of the Guidelines: "the pedagogical proposals of the field schools, respecting the differences and the right to equality and immediately and fully complying with what is established in Articles 23,26 and 28 of Law 9,394/96, contemplated the diversity of the field in all its aspects: social, cultural, political, economic, gender, generation and ethnicity". In the states, the articulations for a field education started to be organized, congregating several institutions, from social movements, NGOs, universities, among others, to consolidate public policies based on the subjects' specificities.

With the approval of the Operational Guidelines for Basic Education in Schools in the Field, instituted by Resolution CNEC/CEB No. 01, of April 3, 2002, there was an advance that contemplated some points discussed and debated in the 1st Conference for a Basic Education in the Field. From then on, the institutions in the field began to observe in their projects the guidelines and principles offered by the guidelines. These, at this historical moment, represent a minimization of contradictions that were historically exposed. So, in this document, in art. 2 , the identity of the school in the field is stated, which "is defined by its attachment to issues inherent to its reality, anchored in the temporality and knowledge of the students [...]" (BRAZIL, Resolution CNEC/CEB no 01, April 3, 2002).

These social movements and the great majority of the Brazilian population, awakened by the democratizing winds, enchanted by the possibility of having an active voice and enveloped by the national and state political conjuncture, in 2002 elected, at the national level, Luís Inácio Lula da Silva and in the state of Paraná, Roberto Requião, opening the concrete possibility for the construction of a University with a differentiated Pedagogical Political Project.

In this context, from 2002 on, regulatory frameworks were built to support the materialization of public policy proposals for education in the countryside, meeting the demands of the National Seminar of 2002, the First National Conference of 1998, and the Second Conference of 2004.

Also in 2004, under Lula's administration, the Secretariat of Continuing Education, Literacy, Diversity and Inclusion - SECADI - was created, which installed, coordinated and managed several programs and projects that contemplated the diversity of the field and that resulted in the legislation in effect. The Secretariat of Continuing Education, Literacy, Diversity and Inclusion - SECADI was the federal government signaling for the mobilizations and demands built by social movements, as we noticed in the National Seminar for a Field Education in 2002. From this Secretariat public policies were built that involved the federal, state and municipal spheres.

As a result of these processes, in September 2012 the Ministry of Education and Culture - MEC and SECADI launched the public call notice no. 02, for the implementation of public policy - National Program for Field Education - PRONACAMPO, which offered conditions for the implementation of 43 Degree Courses in Field Education in Brazil. One of these courses, which had its genesis in this call for proposals, was the Degree in Field Education, Nature Sciences, and its respective Political-Pedagogical Project - PPP, which we implemented at the Federal University of Paraná - UFPR - Coastal Sector. which we now characterize as follows.

\subsection{THE ARCHITECTURE AND FUNDAMENTALS OF THE PEDAGOGICAL PROPOSAL AND CURRICULUM}

The Bachelor's Degree in Education in the Field had as a starting point for its construction the public policies, already mentioned, and the Pedagogical Political Project - PPP - of the Federal University of Paraná - Coastal Sector. This PPP registers as an objective the intention of "consolidating itself as an agent of community development [...] with the perspective of providing the coastal region with extension in the Ribeira Valley, quality of life compatible with human dignity and social justice".

The PPP of UFPR Litoral articulates itself curricularly using the methodology of projects, in which students, through the Learning Projects, are stimulated to critically know the reality, understand the various aspects that structure it and establish integrated actions between the Institution and the community. In addition, the PPP aims at enabling the student to exercise his/her autonomy during the formation process. At the same time, being coresponsible for his/her learning, the student learns to base his/her daily life on local values, without losing the perspective of globalization and respect for human limits, generating self-organization and self-productivity.

Based on the concepts of Cunha (2017) and Sousa Santos (2010), we understand this to be a cosmopolitan education proposal. For Sousa Santos (2010) the cosmopolitan reason is characterized by expanding the present and contracting the future, thus assuming the sociology of absences, which may establish possibilities "to create the 
space-time necessary to know and value the inexhaustible social experience that is underway in the world today" (p. 95), avoiding the waste of experience.

Because the PPP is a local project that takes as its starting point the concrete reality of this place, it builds and makes effective its curricular organization in the dialogue with the subjects of this reality. As a result, the curriculum comes to life through the development of learning projects that start from students and involve teachers and the community.

Being coherent with these principles, the University organizes its curriculum in three learning spaces: a) Learning Projects - PA, corresponds to 20\% of the workload; b) Practical Theoretical Fundamentals - FTP, corresponds to $60 \%$ of the workload; and c) Cultural and Humanistic Interactions - ICH, which with its $20 \%$ workload completes the curriculum.

The sum of the Learning Projects - PA plus the Cultural and Humanistic Interactions - ICH, make up 40\% of the workload of the Course Curriculum and both learning spaces are totally defined by the students. The other $60 \%$ that correspond to the Practical Theoretical Fundamentals - FTP, relate to the specific knowledge of the profession, are planned in a shared way between students and teachers.

The Learning Project - PA - is a space where students exercise the research process since the first semester of the course. However, the methodological process does not follow the outline of a traditional academic research, where the methodology is studied first and then, who knows, at the end of the course to carry out, in one semester, the research and writing of the findings.

In the PA process, the students are provoked, with the help of a mediating professor, to carry out a critical reading of their reality with the intention of reawakening their curiosity process and developing their attitude and philosophical reflection about their environment. As the students deepen their reading of their reality, they are questioned, from their first findings, with the intention of refining their sensitivity and social responsibility. As students of a public university, in addition to the commitment to form good professionals, they also exercise their social and political role with their community by getting to know, think, inquire, with the intention of proposing actions of intervention in their environment.

The Learning Project enables the exercise of authorship by the student, protagonism, development of research as a learning principle and construction of knowledge, therefore, as an educational principle. As this process starts and returns to the reality of the place in the dialogue with the global reality, it necessarily becomes an Intervention Project as well, since from the beginning, the student is invited, provoked to insert himself/herself into the reality to critically know it, collecting subsidies/problems to be studied/resolved. In this movement of comings and goings, without the announcement, research, teaching and extension are happening.

In dialogue with Freire (1997) we understand that:

There is no teaching without research and research without teaching. These tasks are found in each other's bodies. While teaching I keep searching, reprocuring. I teach because I search, because I investigate, because I ask and ask myself. I research to verify, I verify, I intervene, I intervene politely and I educate myself. I research to know what I do not yet know and communicate or announce the novelty (p. 32).

For Freire (1997), the search for the understanding of reality or the overcoming of common sense that interprets reality is the overcoming of naive curiosity, becoming epistemological. It will happen at the moment that, as an educator, one realizes that the research is not something external to his/her to learn/teach, but, yes, inherent to the nature of the very practice of learner and teacher.

The curricular space called Practical Theoretical Foundations - FTP, is destined to attend the National and Operational Curricular Guidelines, specific of the formation for the profession. Therefore, they are modules offered to students, regularly, enrolled in the Course, but that follow the same epistemological logic of the other curricular spaces, that is, they are committed to starting from the concrete reality of the students and the environment in which they live, with them establishing a constant dialogue, in a dialectic movement with the totality.

The FTPs are offered in the form of modules and developed through shared teaching action, whenever possible, grouping two or three teachers. Didatically, the FTPs are developed in various ways, such as project proposals, including case studies, expository classes and dialogued exhibitions, among other possibilities.

The third and last curricular space is called Cultural and Humanistic Interactions - ICH. The ICH is constituted by the relations between scientific, cultural, artistic, popular and personal knowledge, among others. These activities are presented in workshop formats, of regular enrollment, in which the students make a choice, according to their desire and interest in the different processes of cultural interaction. These are modules offered by all the courses 
and the students register independently of being, or not, linked to that course that ICH is offering. Therefore, they are groups formed by students of different courses and different semesters.

The student participates in activities that arouse his/her interest and understanding about human relations. The Cultural and Humanistic Interactions provide a space for the integration of different areas of knowledge, where discussions and reflections on relevant themes are triggered, in order to provide a process of integral formation of the students, considering, mainly, the cultural formation that favors their humanization processes, going, therefore, beyond the technical specificity of the profession, which is also important, but which constitutes only one of the dimensions of the human being.

Corroborating the importance of developing formation through spaces of learning that put the student in contact with the reality of the place in which he/she lives, we highlight what Cunha (1998, p. 15) writes about experiences analogous to this one, calling our attention to the boldness of thinking of a didactic committed to emerging paradigms, where

The experiences that transgress the academic space are, normally, also transgressors of time, having a much more polychronic character, because the world is complex, dense, multidisciplinary, demanding the solution of many things at the same time.

In this context exposed by the author, we understand the need for mediation, which can be understood as the space of relationships involving educator, educating and knowledge. This mediation must include pleasure and enthusiasm as key elements for recovering the subjectivities of those involved in the process. They should also adopt interactive methodologies as projects of action and research, not only from the classroom, but mainly beyond it, because it is the concrete reality (social, economic, political, among others) that should be problematized and serve as a source for the development of training, involving, as a possibility, the new technologies that build complex intellectual skills. In this situation, the study space and/or the classroom space is a place that can be the classroom itself, but it can also be the field - the district, the neighborhood, the city and the world. In this sense, the classroom is only the place of reunion, discussion, exchange of knowledge, new problematizations to replan what one wants to project in order to study and know more.

The methodological option of constructing the curriculum by learning spaces, having as reference the development of learning projects, becomes an instrument that allows the construction of a flexible and alive curriculum, in constant movement. Consequently, the teaching practice assumes the condition of mediator of the teaching and learning process, through actions and relationships led by the subjects of the act of knowledge. The general construction of the PPP and the architecture of the curriculum, are the basis for the construction of the Degree in Field Education, which we understand as a new challenge, to go beyond what has been built so far.

\subsection{THE DEGREE IN FIELD EDUCATION}

The challenges increase or are proportional to the size of the boldness. Recognizing that the role of a public University is to provide a training process for all high school graduates, recognizing also that not everyone can reach the physical building of this University, we built a course that would reach the countryside, the place where these students live and work, which overwhelmingly does not have the economic conditions to attend a University, where it is installed, that is, in the cities.

The Graduate Course in Field Education, from the Federal University of Paraná - UFPR, was created from public policy - National Program for Field Education - PRONACAMPO, which was implemented through the Program to Support Higher Education in Graduate Education in the Field - PROCAMPO, a proposal that emerged from an emerging national context and was welcomed in the local context, UFPR Setor Litoral - Matinhos - Paraná.

The organization of the course was based on the Pedagogy of Alternancy, constituted at the time university and at the time community. However, in organizing the Pedagogical Project of the Course, we took into consideration the social and political role of the university, understanding that, as a public institution, it has the duty to provide objective conditions so that the subjects of the field can exercise their right of access, permanence and success in a university education. To this end, we have included in the project, besides alternation, itinerancy, so that the subjects of the countryside, in the same way as the subjects of the city, could carry out their training without necessarily abandoning their places and their tasks. Thus, the University goes and installs itself in the places where the subjects of the field live and work. The teachers are the ones who move around. 
The organization of the curriculum followed the same proposal of the University, but taking into consideration the realities of the communities in the countryside.

From the perspective of itinerancy, the course was offered in different places. A class was constituted together with the Landless Movement - MST, in a settlement in the municipality of Lapa - PR. The reconstruction of the curriculum was mediated by the reality of this social movement in dialogue with its leaders. Another group was organized together with the subjects of the João Surá Quilombo, in the municipality of Adrianópolis, about $300 \mathrm{~km}$ from the University headquarters. A community formed by descendents of black slaves, which still has its culture very strong, an element that was respected and served as inspiration for the reconstruction of its curriculum. Another class was made up, almost mostly, of teachers who taught but did not have the education of the field. This class was offered in the municipality of Cerro Azul, about $220 \mathrm{~km}$ from the headquarters of UFPR Litoral. The last class was constituted by several movements, having a significant group of indigenous people.

The challenge of this process of education for teachers in the countryside was and is to continue this itinerancy, because although the teachers have given specific and exclusive competition for this course, today many express resistance to remain exclusively in the course, and/or to continue the displacement to different places other than the headquarters of the municipality where the University is located.

In addition to the local context, there are global challenges in reducing the University's budget, a fact that is not the exclusive privilege of one university or another, but is observed more strongly in the campuses that come from the University's expansion process.

Our poet and singer Chico Buarque, already mentioned in this article, inspires us and reminds us of the importance of facing the "living wheel" of life that we dare to face. By forming subjects who are not from the elite, that is, the subjects of the countryside, the workers,

[...] we go against the current until we can't resist. When you get back from the boat you feel how much you've stopped complying. It's been a long time since we cultivated the most beautiful rose tree there is. But behold, the living wheel arrives and carries the rose tree there.

The capacity of local resistance, enhanced by the insertion in a cosmopolitan process, which insists and struggles to amplify the present moment and give voice and turn to the subjects of the countryside, historically excluded from our universities, the process of the roda-viva, requires us to understand that the constructions that dare to install themselves in the opposing hand of this verticality, will be swimming against the current, because it is a question of recognizing that our political action takes place in tension with the global and demarcated by neoliberalism, which does not recognize the workers as subjects of public policy rights.

\subsection{ALIGNING SOME PROVISIONAL CONCLUSIONS}

In this path, to evaluate educational processes is fundamental, because as the poet prudently proposes: "on the return of the boat it is you who feel how much you have stopped fulfilling". A practice thought out, based on what we stopped accomplishing and, also, on how much we advanced and on what we still need to resist, assumes features of praxis, to example of pedagogical practices and the curriculum, allows us to analyze where it has stagnated and where it has allowed us to create new rationalities.

The curriculum organized in learning spaces, where two of these, Cultural and Humanistic Interactions and Learning Projects, are constituted by students, allied to the perspective of human emancipation, opens space for the exercise of democratization, through the construction and reconstruction of knowledge. It is configured as an emancipatory process, where the issues related to their own problems, experienced by academics in the field and the challenges resulting from their contexts and, in and with the communities where they are inserted, are discussed, rethought, built and deconstructed.

In this direction, the "cultivation of the most beautiful rose tree" is possible, in spite of the resistance that comes from the "living wheel". The construction of a differentiated curriculum, flexible and in movement, reflecting and being a reflection of the didactic-pedagogical and epistemological action of teachers and students, is possible and real, but it reveals itself full of contradictions and tensions, which are challenges for the maintenance and expansion of emerging contexts similar to what has been configured here.

Therefore, being this a historical and non-linear process, produced in a neoliberal context, the assumption of contradiction as an element of overcoming is fundamental to materialize hopeful movements. Having clarity of the situation and hopes is essential, but it is not enough, there is a need for them to come accompanied by the necessary 
insertion in the struggle for the "cultivation of the most beautiful rose tree. This struggle is personified in an educational project that does not treat education as a commodity, that values experience as a way to expand and strengthen the present, in order to base a societal project on being a priority in the relationship with having.

\section{SOURCES OF FUNDING}

This research received no specific grant from any funding agency in the public, commercial, or not-for-profit sectors.

\section{CONFLICT OF INTEREST}

The author have declared that no competing interests exist.

\section{ACKNOWLEDGMENT}

None.

\section{REFERENCES}

[1] Arroyo, Miguel gonzalez; Caldart, Roseli Salete; Molina, Mônica Castagna. For a Field Education. Petrópolis, RJ: Vozes, 2004.

[2] Arroyo, Miguel Gonzalez; Fernandes Bernardo Mançano. Basic education and the social movement in the field. Coleção por uma Educação Básica do Campo, nº 02 Brasília, DF: Articulação Nacional Por uma Educação Básica do Campo, 1999.

[3] Brasil, MEC/CNEC/CEB. Operational Guidelines for Basic Education in Field Schools. Resolution no 1, Brasília, DF, 2002.

[4] Brasil, MEC/CNEC/CEB. Diretrizes Operacionais para a educação Básica nas Escolas do Campo. Resolução no 1, Brasília, DF, 2002.

[5] Brasill, MEC/CNEC/CEB. Parecer 36/2001. Operational Guidelines for Basic Education in Field Schools. Brasília, DF, 2001.

[6] Buarque, Chico. Roda viva. III Brazilian Music Festival. 1967.

[7] Cunha, Maria Isabel da. Quality of higher education and the tension between democratization and internationalization at the Brazilian university. In: Cunha, Maria Isabel da (Org.). Internacionalização e democratização: uma tensão na qualidade de educação superior? 2. Ed. São Leopoldo: Oikos, 2017.

[8] Cunha, Maria Isabel da; Fagundes, Maurício. Discutindo projetos emancipatórios no contexto da universidade pública no Brasil. Cadernos de Educação. Universidade Federal de Pelotas, Faculdade de Educação, ano 17, n. 30, jan/jul. 2008. pp.25-44.

[9] Folha de S. Paulo. 1 de agosto de $1997 . \quad$ Disponível em: https://www1.folha.uol.com.br/fsp/1997/8/01/brasil/29.html acesso : 10/09/2019.

[10] Freire, Paulo. Pedagogy of autonomy: knowledge needed for educational practice. São Paulo, SP: Paz e Terra, 1997.

[11] INCRA. História do PRONERA. Disponível em: http://www.INCRA.gov.br/PRONERAhistoria. Acesso em: 10 jun. 2017.

[12] LDB. Law of guidelines and bases of national education 9394/96- Brasília: Senado Federal, Coordenação de Edições Técnicas, 2017.

[13] Kolling, Edgar Jorge, Nery-FSC; MOLINA, Mônica Castagna (Org.) For a Basic Education of the Field: memory. Brasília: Editora Universidade de Brasília, 1999. (Coleção por uma Educação Básica do Campo, no1).

[14] Leite, Sérgio Celani. Rural school: urbanization and educational policies. São Paulo: Cortez, 1999.

[15] MEC/SECADI. Programa Nacional de Educação do Campo PRONACAMPO: guidance document.. Disponível em: http://portal.MEC.gov.br/index.php?option=com_docman\&view=download\&alias=13214-documentoorientador-do-PRONACAMPO-pdf\&Itemid=30192. Acesso em: 10 jun.2018.

[16] Sousa Santos Boaventura. The grammar of time: for a new political culture. 3. Ed. São Paulo: Cortez, 2010. 
The Process of Education in The Field and Teacher Formation in Brazil

[17] Universidade Federal do Paraná - UFPR. Pedagogical Political Project of Setor Litoral. Disponível em: www.litoral.ufpr.br. Acesso em: 10 fev.2020. 